\title{
DYNAMICS OF METEOROLOGICAL AND HYDROLOGICAL DROUGHTS IN THE AGRICULTURAL CATCHMENTS
}

\author{
Katarzyna Kubiak-Wójcicka \\ Nicolaus Copernicus University, Poland \\ kubiak@umk.pl
}

\begin{abstract}
The aim of the paper is to determine the relationship between meteorological drought and hydrological drought in the agricultural basin of the River Osa (northern Poland) in the years 1966-2015. Meteorological droughts appear as a result of insufficient amount or lack of atmospheric precipitation. As a consequence of meteorological droughts occurrences, there appear hydrological droughts which are characterized by low discharges of a river. Standardized Precipitation Index (SPI) and Standardized Runoff Index (SRI) indicators were used for the identification of droughts at various accumulation periods, i.e. 1, 3, 6, 9 and 12 months. In the years 1966-2015, there were identified from 63 (SPI-1) up to 10 meteorological droughts (SPI-12), while hydrological droughts - from 22 (SPI-1) to 8 (SPI-6, 9 and 12). The strongest relationship between the two kinds of droughts occurred in the periods of accumulation from 9 to 12 months. The values of the correlation coefficient between the meteorological and hydrological droughts were above 0.5 in those cases. Those indicators can be used for a system of early drought warning, which is of particular importance for crop production in agricultural areas. Long-lasting meteorological droughts contribute to increase of water intake for irrigation purposes, thus deepening the hydrological drought. As a consequence of the prolonged and intense hydrological drought, further irrigation may be impossible due to too low river discharges. Key words: meteorological drought, hydrological drought, SPI, SRI, River Osa, Poland.
\end{abstract}

\section{Introduction}

According to the latest climate forecasts, the frequency of extreme weather conditions, and thus the occurrence of droughts is expected to increase (IPCC, 2013). As a consequence of further climate warming and changes in the spatial and seasonal distribution of atmospheric precipitation, changes in the hydrological regime of rivers and water resources take place. In the present climate, many regions of Poland often suffer from water shortage, especially during the vegetation season. In the future, this shortage may become even more serious which may result in limitations in the availability of water resources. In recent years, changes in the course of climate phenomena in Poland have been observed more and more frequently, which especially applies to the increase of air temperature (Tomczyk \& Szyga-Pluta, 2018). Annual precipitation amounts in Poland only slightly change (slight increase), but what is important, major changes occur in seasonal and monthly precipitation patterns (Szwed, 2018).

An important problem is the impact of changing meteorological factors on the seasonal and longterm scale on the occurrence of meteorological and hydrological droughts. Relations between meteorological and hydrological droughts were the subject of research by various authors (Shukla \& Wood, 2008; Lorenzo-Lacruz et al., 2013; Fendeková et al., 2018). Studies on the relationship between the courses of kinds of droughts, using various indicators, were conducted in Poland by Tokarczyk \& Szalińska (2018), Somorowska (2009), Kubiak-Wójcicka \& Bąk (2018). Kuśmierek-Tomaszewska et al. (2019) on the basis of meteorological and agricultural drought indicators determined shortages of precipitation in field crops production on agricultural areas.
The main aim of the paper is to analyze the course of meteorological and hydrological droughts and to assess their mutual relationship. The Osa agricultural catchment, located in northern Poland, was used for analysis. The increase in threat of meteorological drought results in an increase in hydrological drought, which is extremely important for agricultural areas and the volume of plant production, as well as the possibility of irrigation of these areas.

\section{Materials and Methods}

To determine the meteorological drought, the average monthly totals sums of precipitation obtained for 2 meteorological stations, i.e. Radzyń Chełmiński and Gardeja were used. In turn, hydrological characteristics were used for data on discharges of the River Osa in the Rogóźno profile. The location of the stations is shown in Figure 1. Meteorological and hydrological data were obtained from the Institute of Meteorology and Water Management - National Research Institute (in Polish IMGW-PIB). They cover the period from 1965 to 2015 .

Meteorological droughts were identified on the basis of a standardised precipitation index (SPI). The SPI index was calculated for the meteorological station Radzyń Chełmiński. The SRI (Standardized Runoff Index) for the discharges of the River Osa recorded at gauging station Rogóźno was used to determine the hydrological drought. The values of the indices are calculated as standard deviation of atmospheric precipitation or discharge from the respective median value in the analysed multi-year period. The precipitation totals have been normalised with a function $f(P)=(P)^{1 / 3}$, and for the discharge sums the normalization function was a 2-parameter 


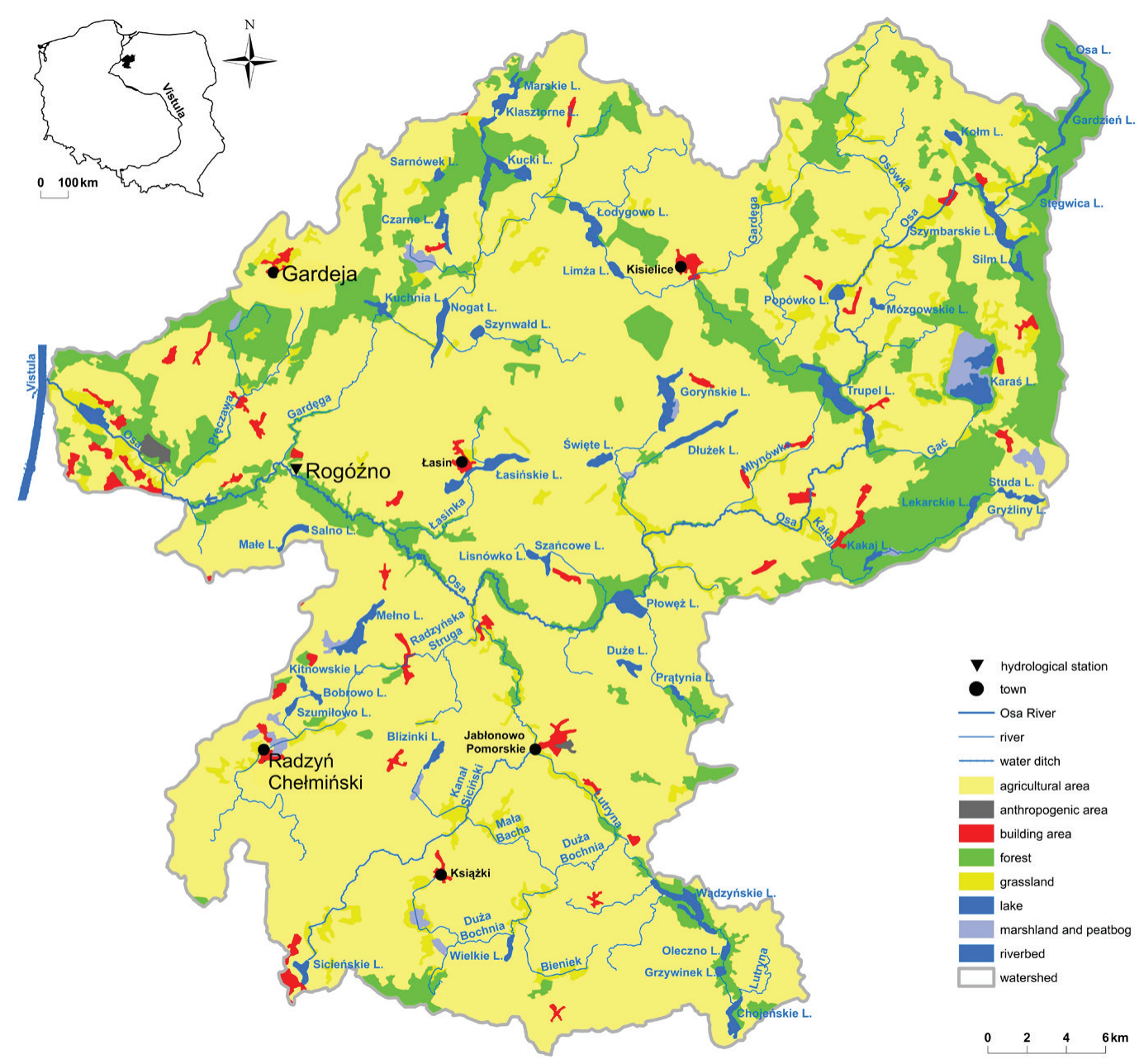

Figure 1. Land use in the River Osa basin on the basis of the Corine together with hydrological and meteorological stations.

logarithmic function (Bąk \& Kubiak-Wójcicka, 2016, 2017). The drought intensity classification was carried out in accordance with Table 1.

The long-term (usually many months) period of small sums of rain or temporary lack of precipitation contributes to formation of the hydrological drought. The paper uses various sets of accumulated sums of precipitation and discharge, i.e. 1, 3, 6, 9 and 12 months. Previous studies have shown that short periods of accumulation are suitable for small catchments that react quickly to changes in meteorological conditions (Barker et al., 2015). An important issue for agricultural areas is understanding the relationship between the course of meteorological drought and its impact on hydrological drought. The relationship between two droughts was presented with the use of the correlation coefficient $r$. The higher the correlation coefficient, the stronger the relation. According to the studies of other authors, a significant correlation between the course of both droughts occurs when $r>0.5$.

The research area is the Osa catchment, whose total area is $1606.27 \mathrm{~km}^{2}$. The Osa River is a secondorder watercourse, the right tributary of the Vistula.

Classification of drought intensity (McKee, Doesken, \& Kleist, 1995)

\begin{tabular}{|c|c|}
\hline SPI, SRI & Intensity of drought \\
\hline$<-2.0$ & extremely dry \\
-1.99 to -1.5 & severely dry \\
-1.49 to -1.0 & moderately dry \\
-0.99 to 0.0 & mild dry \\
\hline
\end{tabular}



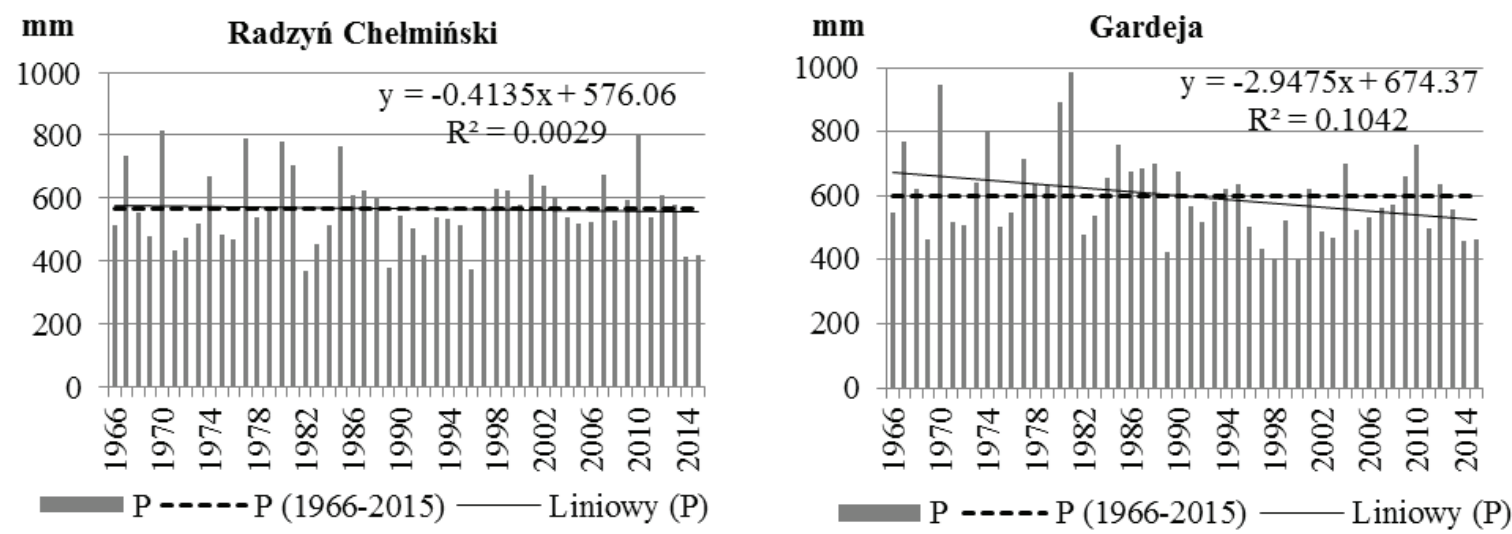

Figure 2. Multiannual course of average annual precipitation at meteorological stations Radzyń Chełmiński and Gardeja in the years 1966-2015.

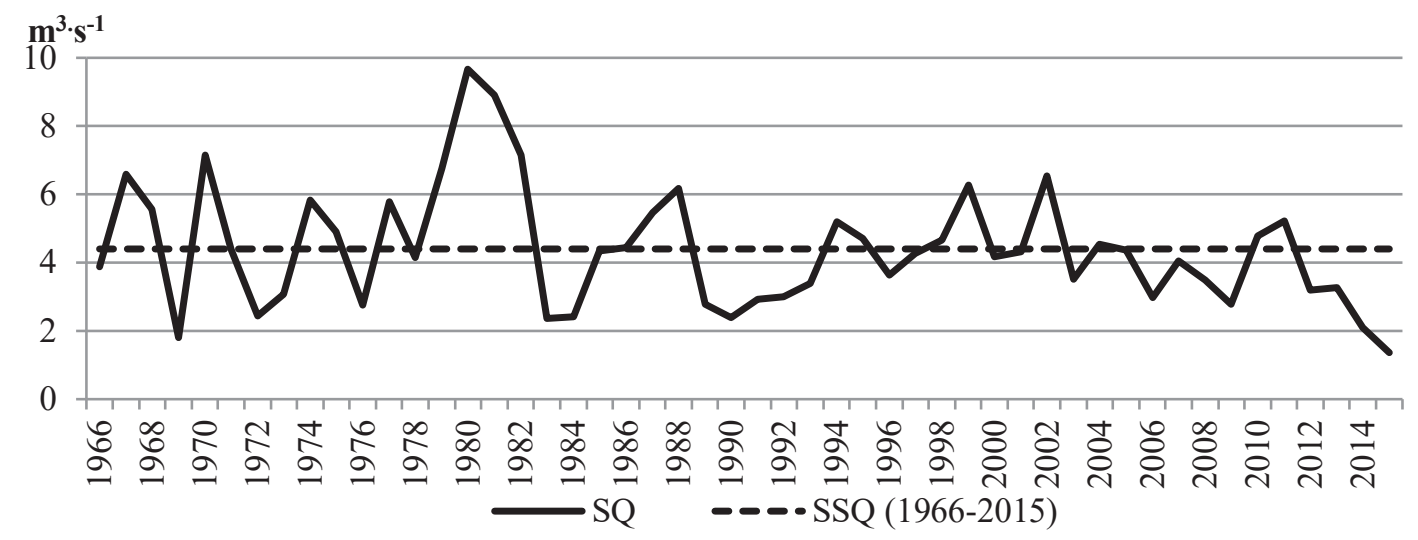

Figure 3. Average annual discharge of the Osa (SQ) at the background of multi-year discharge (SSQ) at hydrological station Rogóźno in the years 1966-2015.

The Osa originates from Lake Parkun and flows into the Vistula, north of Grudziądz. The length of the Osa River is $109.84 \mathrm{~km}$. The most important tributaries of the Osa are the Lutryna and Gardęga rivers, which flow into the Osa below the hydrological station in Rogóźno (Figure 1). The hydrological station in Rogóźno closes the catchment area of $1135.11 \mathrm{~km}^{2}$ (Atlas podziału hydrograficznego Polski, 2005). In terms of land use, arable land predominates, accounting for almost $70 \%$ of the catchment area. Forests occupy $14.4 \%$ of the catchment, meadows $10 \%$ and swamps $-1.78 \%$ (Figure 1). Currently, there are 12 lakes greater than 100 ha in the Osa basin. The largest are the following lakes: Karaś, Trupel, Goryńskie, Kucki and Wądzyńskie.

\section{Results and Discussion}

During the analysed period of 1966-2015, the average atmospheric precipitation total at the meteorological station in Radzyń was $565.5 \mathrm{~mm}$, while in Gardeja - 599.2 mm (Figure 2). These values are among the lowest in Poland. The analysis of annual precipitation totals at the Gardeja site presents a statistically significant downward trend, while the annual precipitation sums even at the Radzyn Chełmiński meteorological station. These results are in line with the studies carried out at various comparative periods by Czarnecka \& Niedzgorska-Lencewicz (2012) and Szwed (2018). Precipitation during the vegetation season (April-September) in Radzyń accounted for $63 \%$ of whole year precipitation, while in Gardeja it was 60\%. The lowest precipitation at the meteorological station in Radzyń was recorded in 1982 and at the Gardeja station in 2000. Low annual precipitation in these particular years occurred also in the entire Kuyavian-Pomeranian region (KuśmierekTomaszewska et al., 2018).

The average long-term flow of the River Osa recorded at the Rogóźno hydrological station was $4.40 \mathrm{~m}^{3} \mathrm{~s}^{-1}$, which implies a specific discharge of $3.9 \mathrm{dm}^{3} \mathrm{~s}^{-1} \mathrm{~km}^{-2}$. The specific discharge from the Osa catchment is one of the lowest in Poland. For the comparison, the average specific discharge from the entire Vistula basin in the period 1951-2015 was 
Parameters and indices of meteorological and hydrological drought in the years 1966-2015

\begin{tabular}{|l|c|c|l|l|}
\hline & $\begin{array}{c}\text { Total number of drought } \\
\text { occurrences }\end{array}$ & $\begin{array}{c}\text { Number of months with a drought } \\
\text { (SPI or SRI <-1.0) }\end{array}$ & \multicolumn{1}{|c|}{$\begin{array}{c}\text { The longest drought } \\
\text { span (months) }\end{array}$} & $\begin{array}{c}\text { Maximum drought } \\
\text { intensity }\end{array}$ \\
\hline SPI-1 & 63 & 197 & 9 (I1989-IX1989) & -3.16 (I 1997) \\
\hline SPI-3 & 42 & 215 & 19 (VI2014-XII2015) & -3.07 (I 1997) \\
\hline SPI-6 & 42 & 205 & 24 (IX1991-VIII1993) & -2.96 (XII 1982) \\
\hline SPI-9 & 13 & 224 & 35 (VIII1971-VI 1974) & -2.85 (VI 1996) \\
\hline SPI-12 & 10 & 247 & 36 (X 1971-IX 1974) & -2.33 (V 2015) \\
\hline SRI-1 & 22 & 206 & 29 (VIII 2013-XII 2015) & -2.42 (III 2015) \\
\hline SRI-3 & 15 & 212 & 33 (IX 1982-V 1985) & -2.62 (V 2015) \\
\hline SRI-6 & 8 & 256 & 48 (IV 1989-I 1994) & -2.80 (VIII 2015) \\
\hline SRI-9 & 8 & 237 & 57 (V 1989-I 1994) & -2.84 (X 2015) \\
\hline SRI-12 & 8 & 248 & 57 (VI 1989-II 1994) & -2.69 (XI 2015) \\
\hline
\end{tabular}

$5.39 \mathrm{dm}^{3} \mathrm{~s}^{-1} \mathrm{~km}^{-2}$ (Kubiak-Wójcicka, 2019). The highest annual discharge of the Osa was recorded in 1980 and it was twice as high as the average value from the period 1966-2015. The lowest discharge occurred in 2015 and amounted to $1.36 \mathrm{~m}^{3} \mathrm{~s}^{-1}$, which gave specific discharge of $1.2 \mathrm{dm}^{3} \mathrm{~s}^{-1} \mathrm{~km}^{-2}$. Throughout the period 1966-2015, there is a clear downward trend in the discharge. The annual distribution is dominated by the discharge in the cold half-year (October-March) $57 \%$ over the discharge in summer (April-September), which accounted for $43 \%$ of the discharge during a year (Figure 3).Meteorological droughts in 1-month cumulative periods are characterized by the highest quantity (63), the shortest duration of the longest drought (9 months) and the highest intensity (-3.16) (Table 2). With the increase of the accumulation period, the number of meteorological droughts decreased (10 droughts for SPI-12) and the maximum intensity decreased (-2.33 for SPI-12). The maximum duration of the longest drought has extended and the number of months with meteorological droughts has increased. Hydrological droughts were characterized by a smaller number of events than meteorological droughts, especially in short periods of accumulation, i.e. from 1 to 3 months. In the longer period of accumulation (6-12 months), hydrological droughts were grouped, the number of months with a drought increased, and the duration of the longest drought increased. The most intense droughts in the Osa catchment were recorded in 2015. The hydrological drought, which took place in 2015 (SRI-1), covered all of Poland, and, in the Osa catchment, was one of the most severe (SPI / SRI $<=-2.0$ ) and possibly the longest because it extended to 2016. 2015 was one of the driest years in terms of precipitation and temperature anomalies in Central Europe in the last 15 years (Fendekova et al., 2018; Laaha et al., 2017). The longest lasting hydrological droughts in the Osa catchment occurred in 1989-1994. The drought in those years became disastrous and covered almost the entire area of Poland (Łabędzki, 2007). The course of the drought in the individual accumulation periods is shown in Figure 4.

Correlation coefficients between SRI and SPI were the highest for the 9-month (February) and 12-month (May) cumulative period (0.76) (Table 3). The largest correlations between droughts occurred in the cold half-year (October-March) in periods of 6 and 9 months, and the correlation coefficient (r) was 0.65 and 0.67 , respectively. The highest annual correlation coefficient was obtained for a period of 12 months $(\mathrm{r}=0.63)$, where $\mathrm{r}$ values are higher than 0.5 in all months, which indicates a high degree of dependence. The obtained results are consistent with the research of other authors. The high correlation coefficient between meteorological and hydrological droughts (annual $\mathrm{r}$ index above 0.5) was identified by Ljubenkov \& Cindrić Kalin (2016) for the 6, 9 and 12-month accumulation periods for the rivers of Croatia. Higher correlation coefficients between droughts were obtained by Vicente-Serrano \& LópezMoreno (2005) for mountainous rivers in the Spanish Pyrenees, where fast surface runoff dominates in shorter time intervals, i.e. 1-2 months and Barker et al. (2015) for the rivers of England. Tokarczyk \& Szalinska (2018) showed that the greatest correlations between SPI and SRI occurred in 12 to 24 months of accumulation for Prosna, while for Nysa Kłodzka in the accumulation periods from 18 to 24 months. In the case of large catchments, e.g. the Vistula basin, the greatest strength of the relationship was in longer periods of 18 and 24 accumulation (Kubiak-Wójcicka \& Bąk, 2018). Relatively low values of correlation between droughts were recorded by Rimkus et al. (2013) in the basin of the Neman River. To a large extent, the impact of meteorological drought on 


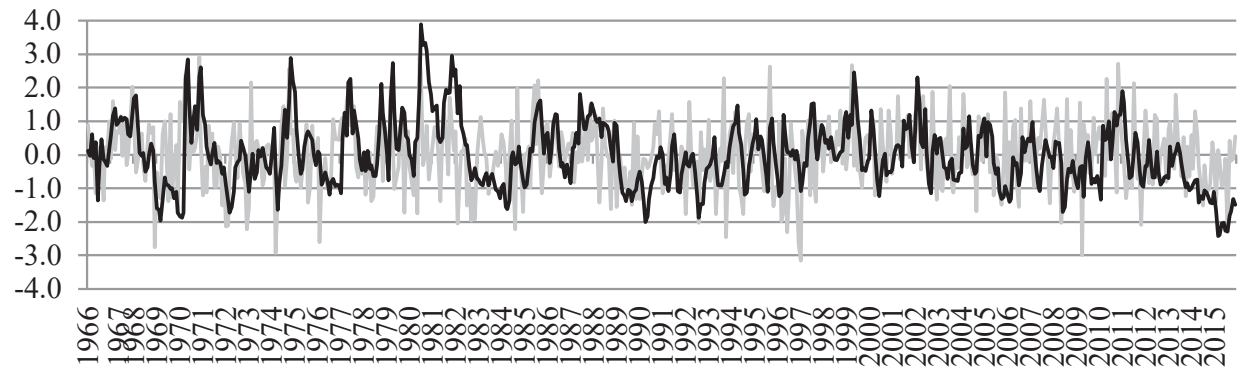

— SPI-1 Radzyń Chełmiński — - SRI-1 Rogóźno

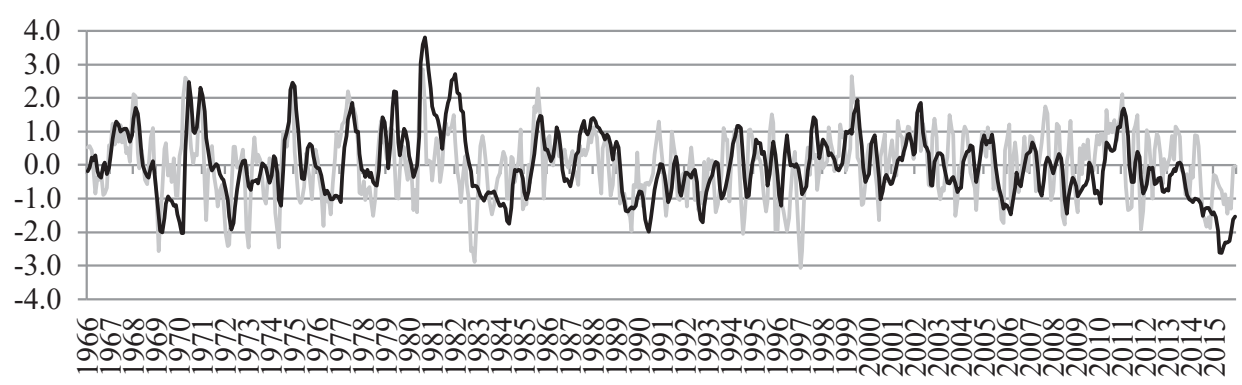

—SPI-3 Radzyń Chełmiński — SRI-3 Rogóźno

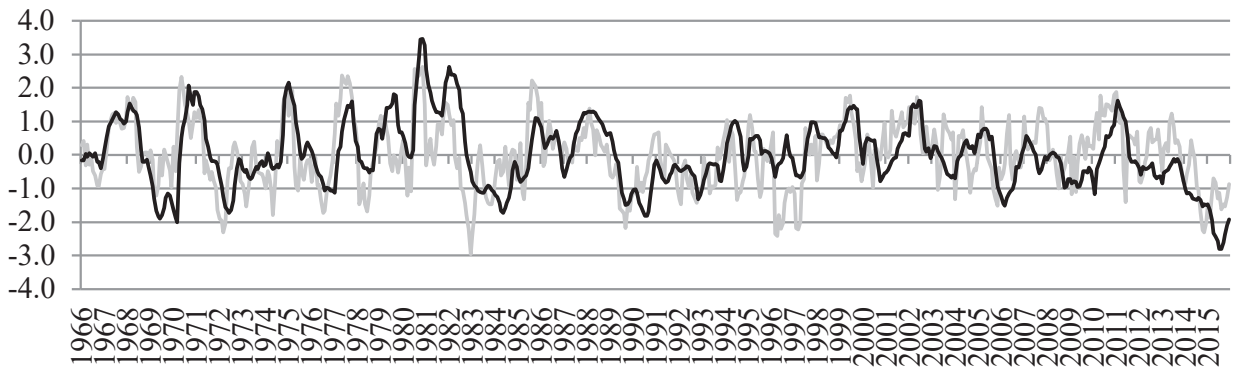

—SPI-6 Radzyń Chełmiński —SRI-6 Rogóźno

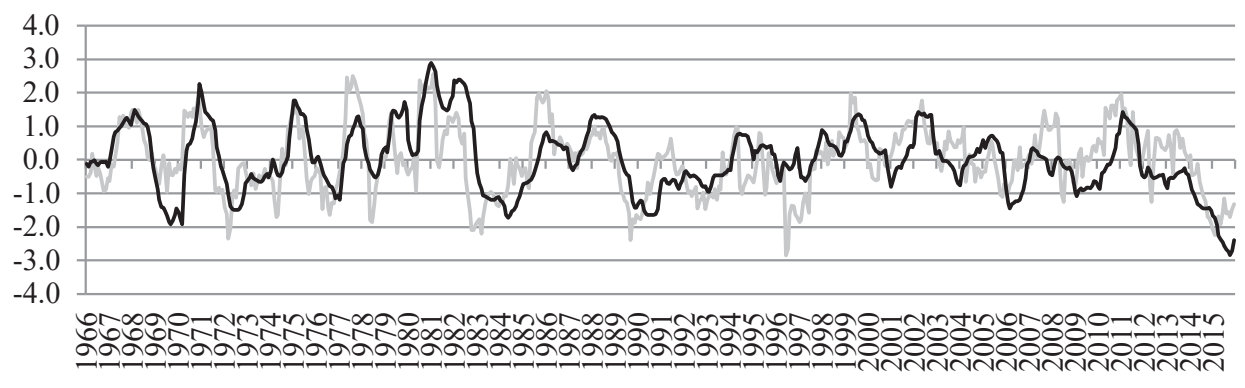

—SPI-9 Radzyń Chełmiński —SRI-9 Rogóźno

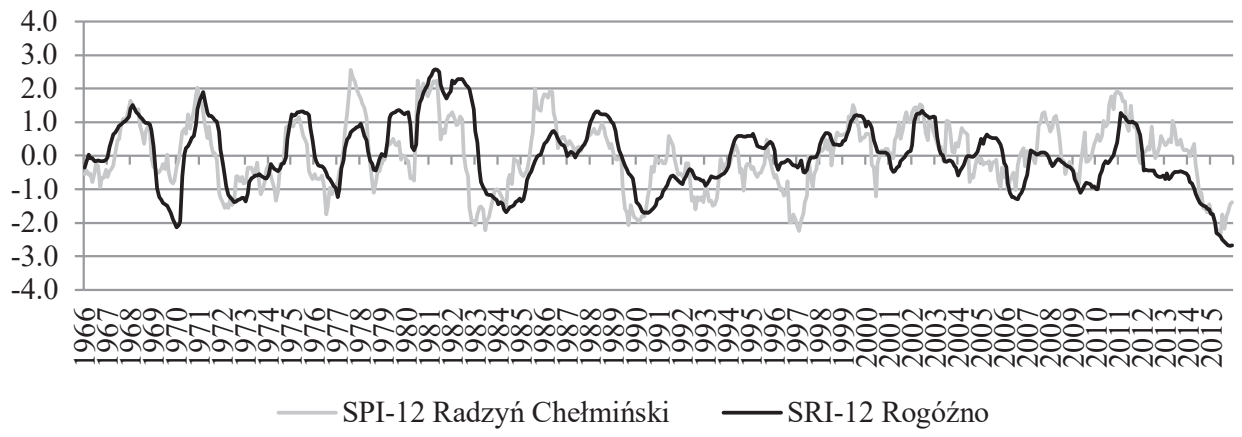

Figure 4. The course of indices SPI and SRI in various time scales in the years 1966-2015. 
The coefficient of correlation between meteorological drought and hydrological drought during a year

\begin{tabular}{|l|c|c|c|c|c|c|c|c|c|c|c|c|}
\hline \multicolumn{1}{|c|}{ Months } & 1 & 2 & 3 & 4 & 5 & 6 & 7 & 8 & 9 & 10 & 11 & 12 \\
\hline SPI-1 vs SRI-1 & 0.14 & 0.16 & 0.30 & 0.29 & 0.21 & 0.53 & 0.52 & 0.29 & 0.17 & 0.26 & 0.39 & 0.32 \\
SPI-3 vs SRI-3 & 0.42 & 0.38 & 0.29 & 0.37 & 0.39 & 0.36 & 0.53 & 0.70 & 0.53 & 0.42 & 0.50 & 0.54 \\
SPI-6 vs SRI-6 & 0.57 & 0.62 & 0.64 & 0.54 & 0.40 & 0.37 & 0.47 & 0.55 & 0.57 & 0.65 & 0.75 & 0.69 \\
SPI-9 vs SRI-9 & 0.69 & 0.76 & 0.72 & 0.66 & 0.60 & 0.53 & 0.50 & 0.48 & 0.47 & 0.57 & 0.60 & 0.68 \\
SPI-12 vs SRI-12 & 0.62 & 0.66 & 0.69 & 0.73 & 0.76 & 0.70 & 0.63 & 0.59 & 0.54 & 0.52 & 0.50 & 0.57 \\
\hline
\end{tabular}

hydrological drought is conditioned by the physical and geographical features of the catchment (geological structure, land use, catchment size).

The obtained results show that the Osa's agricultural catchment reacts quickly to the lack of atmospheric precipitation or insufficient amount of precipitation. During periods of meteorological drought in agricultural areas, irrigation is applied, which not only prevents crop decline, but it also allows to achieve a higher level of yields compared to the average without the use of this procedure (Żarski et al., 2017). Hydrological droughts, which are the result of long-lasting meteorological droughts, additionally deepen due to increased water intake for the needs of irrigation. In the case of prolonged hydrological droughts, the possibility of land irrigation will be limited due to low flows in rivers. It is necessary to take measures to increase local water resources, as well as the use of technology that allows economical use of water for the needs of agricultural production.

\section{Conclusions}

The results obtained allowed to formulate the following conclusions:

1. meteorological droughts in the Osa basin in the years 1966-2015 are characterized by more events, intensity and a longer maximum duration than hydrological droughts;

2. with the increase of the accumulation period, the number of meteorological and hydrological droughts is reduced, while the total duration of droughts is increased, which results from the grouping of droughts in longer periods of accumulation, e.g. 9 and 12 months;

3. the relationship between meteorological and hydrological droughts is presented in the form of a correlation coefficient between the SPI and the SRI during the same accumulation periods;

4. the highest correlation coefficient between the SPI and the SRI was obtained for the 9 and 12-month accumulation periods $(\mathrm{r}=0.76)$;

5. the highest annual correlation coefficient was obtained for 12-month accumulation period $(r=0.63)$; the $r$ values are higher than 0.5 in all months;

6. hydrological droughts determined on the basis of the SRI indicator inform about water resources within the whole catchment;

7. SPI and SRI indicators can be used for monitoring and early warning against drought, which is crucial for agriculture, especially during the vegetation season.

\section{References}

1. Atlas podziatu hydrograficznego Polski (Atlas of hydrographic division of Poland). (2005). Warszawa. (in Polish)

2. Barker, L.J., Hannaford, J., Chiverton, A., \& Svensson, C. (2015). From meteorological to hydrological drought using the standardized indicators. Hydrol. Earth Syst. Sci. Discuss., 12, 12827-12875. DOI: 10.5194/hessd-12-12827-2015.

3. Bąk, B., \& Kubiak-Wójcicka, K. (2016). Assessment of meteorological and hydrological drought in Torun (central Poland town) in 1971-2010 based on standardized indicators. In P. Gastescu \& P. Bretcan (Eds.), $3^{\text {rd }}$ International Conference Water resources and wetlands Conference proceedings. (pp. 164-170). Tulcea: Romania. Retrieved February 26, 2019, from https://www.limnology.ro/wrw2016/proceedings/22_Bak Kubiak.pdf.

4. Bąk, B., \& Kubiak-Wójcicka, K. (2017). Impact of meteorological drought on hydrological drought in Toruń (central Poland) in the period of 1971-2015. Journal of Water and Land Development, 32(I-III), 3-12. DOI: 10.1515/jwld-2017-0001.

5. Czarnecka, M., \& Niedzgorska-Lencewicz, J. (2012). Wieloletnia zmienność sezonowych opadów w Polsce (Multiannual variability od seasonal precipitation in Poland). Woda-Środowisko-Obszary Wiejskie, 12, 2, 45-60. (in Polish) 
6. Fendeková, M., Gauster, T., Labudová, L., Vrablíková, D., Danáčová, Z, Fendek, M., \& Pekárová, P. (2018). Analysing $21^{\text {st }}$ century meteorological and hydrological drought events in Slovakia. J. Hydrol. Hydromech, 66, 4, 393-403. DOI: 10.2478/johh-2018-0026.

7. Kubiak-Wójcicka, K., \& Bąk, B. (2018). Monitoring of meteorological and hydrological droughts in the Vistula basin (Poland). Environ Monit Assess, 190, 11, 1-16. DOI: 10.1007/s10661-018-7058-8.

8. Kubiak-Wójcicka, K. (2019). Long-term variability of runoff of Vistula River in 1951-2015. "Air and Water - Components of the Environment" Conference Proceedings, Cluj-Napoca, Romania, 109-120. DOI: $10.24193 / A W C 2019 \_11$.

9. Kuśmierek-Tomaszewska, R., Dudek, S., Żarski, J., \& Januszewska-Klapa, K. (2018). Temporal variability of drought in field crops in the region of Kujawsko-Pomorskie, Poland. Agricultural Sciences (Crop Sciences, Animal Sciences). Research Rural Development, 2, 62-68. DOI: 10.22616/rrd.24.2018.052.

10. Laaha, G., Gauster, T., Tallaksen, L.M., Vidal, J-P., Stahl, K., Prudhomme, Ch., Heudorfer, B., Vlnas, R., Ionita, M., Van Lanen, H.A.J., Adler, M-J., Caillouet, L., Delus, C., Fendekova, M., Gailliez, S., Hannaford, J., Kingston, D., Van Loon, A.F., Mediero, L., Osuch, M., Romanowicz, R., Sauquet, E, Stagge, J.H., \& Wong, H.W. (2017). The European 2015 drought from a hydrological perspective. Hydrol. Earth Syst. Sci., 21, 3001-3024. DOI: 10.5194/hess-21-3001-2017.

11. Ljubenkov, I., \& Cindrić Kalin, K. (2016). Evaluation of drought using standardised precipitation and flow indices and their correlations on an example of Sinjsko polje. Gradevinar, 2, 135-143. DOI: 10.14256/ JCE.1337.2015.

12. Lorenzo-Lacruz, J., Vicente-Serrano, S.M., González-Hidalgo, J.C., López-Moreno, J.I., \& Cortesi, N. (2013). Hydrological drought response to meteorological drought in the Iberian Peninsula. Clim. Res., 58, $117-131$.

13. Łabędzki, L. (2007). Estimation of local drought frequency in central Poland using Standardized Precipitation Index SPI. Irrigation and Drainage, 56, 67-77. DOI: 10.1002/ird.285.

14. McKee, T.B., Doesken, N.J., \& Kleist, J. (1995). Drought monitoring with multiple time scales. Preprints of the 9th Conference of Applied Climatology, 15-20 January 1995, Dallas, pp. 233-236.

15. Rimkus, E., Stonevičius, E., Korneev, V., Kažys, J., Valiuškevičius, G., \& Pakhomau, A. (2013). Dynamics of meteorological and hydrological droughts in the Neman river basin. Environ. Res. Lett. 8, DOI: 10.1088/1748-9326/8/4/045014.

16. Shukla, S., \& Wood, W. (2008). Use of a standardised runoff index for characterizing hydrologic drought. Geophysical Research Letters, 35, L02405. DOI: 10.1029/2007GL032487.

17. Somorowska, U. (2009). Wzrost zagrożenia suszą hydrologiczną w różnych regionach geograficznych Polski w XX wieku (Increase in the hydrological drought risk in different geographical regions of Poland in the 20th century). Prace $i$ Studia Geograficzne, 43, 97-114. (in Polish)

18. Szwed, M. (2018). Variability of precipitation in Poland under climate change. Theoretical and Applied Climatology. DOI: 10.1007/s00704-018-2408-6.

19. The Intergovernmental Panel on Climate Change (IPCC). Climate change (2013). The physical science basis. In Contribution of Working Group I to the 5th Assessment Report of the Intergovernmental Panel on Climate Change; Cambridge University Press: Cambridge, UK; New York, NY, USA, 2013.

20. Tokarczyk, T., \& Szalińska, W. (2018). Drought hazard assessment in the process of drought risk management. Acta Sci. Pol. Formatio Circum., 17(3), 217-229. DOI: 10.15576/ASP.FC/2018.17.3.217.

21. Tomczyk, A.M., \& Szyga-Pluta, K. (2018). Variability of thermal and precipitation conditions in the growing season in Poland in the years 1966-2015. Theoretical and Applied Climatology. DOI: 10.1007/ s0070401824504.

22. Vicente-Serrano, S.M., \& López-Moreno, J.I. (2005). Hydrological response to different time scales of climatological drought: an evaluation of the Standardized Precipitation Index in a mountainous Mediterranean basin. Hydrol. Earth Syst. Sci., 9, 523-533. DOI: 10.5194/hess-9-523-2005.

23. Żarski, J., Dudek, S., Kuśmierek-Tomaszewska, R., \& Żarski, W. (2017). Effects of agricultural droughts in the province of Kujawsko-Pomorskie and possibilities of minimizing their impact. Infrastructure and Ecology of Rural Areas, II(2), 813-824. DOI: 10.14597/infraeco.2017.2.2.063. 